\title{
De hospitalera en de pelgrim, over gastvrijheid en identiteit
}

Suzanne van der Beek*

\section{Summary}

Hospitality plays a significant role in the experience of the modern pilgrimage to Santiago de Compostela. On this journey, hospitality is primarily found in the interaction between the hospitalera (someone who hosts pilgrims at specialized hostels) and the pilgrim. This paper explores the relation between these two figures and argues that this relationship is formed by the presentation, the recognition, and the confirmation of identity. The pilgrim, as a guest, expects a certain amount of hospitality from the Camino, this expectation is a part of the pilgrim's identity package. The hospitalera, as a host, claims the authority to decide which guests possess a pilgrim identity and are therefore eligible for their hospitality. The hospitality that is experienced on the Camino to Santiago de Compostela is therefore conditional. It offers both the hospitalera and the pilgrim the opportunity to confirm and strengthen the desired identity in both themselves and the other.

\section{Introductie}

Pelgrims op weg naar Santiago de Compostela ervaren deze tocht als waardevol om verschillende redenen, zoals het loslaten van het dagelijks leven, de ontmoetingen met nieuwe personen, de mogelijkheid voor spirituele ervaringen en de verbinding met een eeuwenoude traditie. Op deze lijst neemt ook het ervaren van gastvrijheid een hoge positie in. Gastvrijheid wordt vormgegeven door ten minste twee partijen: de gastvrouw en de gast. ${ }^{1}$ Op de pelgrimstocht naar Santiago de Compostela worden deze rollen voornamelijk vertolkt door de hospitalera (iemand die gastvrijheid biedt aan pelgrims) en de pelgrim. In dit artikel wordt de relatie tussen deze twee figuren in de context van gastvrijheid en identiteit verkend. Om de achtergrond te schetsen voor dit onderzoek, begint dit artikel met een anekdote.

Dit voorval vond plaats in mei 2014. Ik nam voor de eerste keer deel aan de pelgrimstocht naar Santiago de Compostela en liep met vele medepelgrims

* Suzanne van der Beek is als universitair docent verbonden aan de Tilburg School of Humanities and Digital Sciences. 
door het noorden van Spanje. Ik was slechts twee dagen eerder, samen met mijn moeder, in de Pyreneeën begonnen aan mijn tocht. We hadden deze dag maar liefst 28 kilometer gelopen, het was een warme dag geweest en we waren opgelucht dat we waren aangekomen in het kleine stadje Larrasoaña, waar we een bed hadden bemachtigd in de enige pelgrimsherberg. Nadat we ons bed hadden opgemaakt, een douche hadden genomen en een avondmaaltijd hadden gereserveerd, vonden we een plekje in de schaduw om een biertje te drinken en in onze dagboeken te schrijven. Terwijl wij daar samen zaten, zagen we $\mathrm{Adam}^{2}$ het stadje binnenlopen. We hadden Adam al voor de reis in Nederland ontmoet, dus we wuifden hem enthousiast naar ons tafeltje. Hij liep samen met twee andere Nederlandse pelgrims die hij onderweg had ontmoet. $\mathrm{Na}$ een vrolijk gesprek ging het groepje op ons aanraden op pad om een plekje te vinden in dezelfde albergue waar wij die avond zouden overnachten. Niet veel later kwam de groep terug in bedrukte stemming: de albergue was vol en er was geen andere mogelijkheid om ergens te overnachten in Larrasoaña. Het groepje vertelde dat zij na het horen van dit nieuws om hulp hadden gevraagd bij verschillende lokale autoriteiten, maar overal waar zij hadden aangebeld waren zij weggestuurd. De pelgrims waren verward en teleurgesteld - alle verhalen over deze pelgrimstocht vertellen immers over de eindeloze gastvrijheid van de Camino. Ze drukken de pelgrim op het hart om zich geen zorgen te maken: als je in de problemen komt, dan klop je simpelweg aan bij de kerk of de politie. Zij zullen altijd voor je zorgen. Maar deze instanties waren die dag allebei niet bereikbaar. De verhalen hadden ons ook voorbereid op de bereidheid van de mensen die langs de pelgrimstocht wonen om onderdak te bieden aan gestrande pelgrims, maar ook deze gastvrijheid bleef uit voor Adam en zijn metgezellen. Uiteindelijk vond het groepje pelgrims iemand die bereid was om - tegen betaling - een taxi voor hen te bellen zodat zij konden overnachten in een hotel in een stadje verderop. Adam en zijn vriend Peter waren voornamelijk teleurgesteld, maar hun vriendin Naomi was woedend. Zij bleef maar roepen: "Is dit nu de Camino?!" De reactie van Naomi en haar herhaaldelijke uitroepen zijn me lang bijgebleven. Het was de eerste keer dat ik inzicht kreeg in de centrale positie die de traditie van gastvrijheid inneemt in de bevestiging van de pelgrimsidentiteit. Voor Naomi bestond de een niet zonder de ander: "Hoe kan het zijn dat ik geen gastvrijheid ontvang? Ik ben toch zeker pelgrim?" In dit artikel presenteer ik een verkenning van de dynamiek rond gastvrijheid op de pelgrimstocht naar Santiago de Compostela in de context van de constructie van de moderne pelgrimsidentiteit. ${ }^{3}$ 


\section{Doel en methode van het onderzoek}

In de verkenning van de dynamiek rond gastvrijheid speelt mijn eigen identiteit een belangrijke rol. In dit artikel worden mijn ervaringen als pelgrim en als hospitalera verkend om tot een analytisch begrip te komen van de positie die gastvrijheid inneemt in de constructie van een pelgrimsidentiteit. Deze methode is gebaseerd op Leon Andersons 'analytische auto-etnografie' (Anderson 2006). Auto-etnografische methoden zijn ontwikkeld om verschillende complicaties binnen de etnografische traditie aan te kaarten. De centrale complicatie die aan de orde wordt gesteld, is de positie die de onderzoeker inneemt binnen het veld waarin observaties worden verricht. De autoetnograaf plaatst zichzelf expliciet binnen de te observeren gemeenschap en maakt die betrokkenheid van de onderzoeker in het veld zelf een extra moment van analyse. Op deze manier worden niet alleen de bevindingen met de lezer gedeeld, maar ook belangrijke elementen uit het proces waarin de analyse tot stand kwam. Andere complicaties die via auto-etnografische strategieën worden opgepakt zijn de vervaging van de grenzen tussen (auto)biografisch en etnografisch schrijven, de toenemende interesse in emoties binnen de sociale wetenschappen, en een postmodern scepticisme ten opzichte van kennis die gegeneraliseerd wordt uit externe observaties (Anderson 2006, 373).

De methode die Anderson voorstelt, welke wordt gehanteerd in dit artikel, bestaat uit drie belangrijke pijlers (Anderson 2006, 375):

1. De onderzoeker is een volledig lid van de gemeenschap die wordt bestudeerd. Tussen 2014 en 2019 heb ik zeven routes naar Santiago de Compostela gelopen. In deze maanden heb ik een persoonlijke relatie ontwikkeld met de steeds veranderende pelgrimsgemeenschap. Zodoende reken ik mijzelf inderdaad volledig tot deze pelgrimsgemeenschap;

2. De onderzoeker toont dit lidmaatschap in haar publicaties. In deze en andere publicaties draag ik er zorg voor om mijn hybride identiteit - zowel onderzoeker als pelgrim of hospitalera - zichtbaar te maken;

3. Het onderzoek draagt bij aan de ontwikkeling van een theoretisch begrip van het onderzoeksonderwerp. Dit laatste element is van bijzonder belang, omdat het de onderzoeker ervoor behoedt om analyses te schrijven die geen aansluiting vinden binnen de bredere academische discussie over, in dit geval, pelgrimeren en gastvrijheid.

Via deze stappen brengt de onderzoeker de onderhandelingen die plaatsvinden rond identiteit en sociale positionering expliciet naar voren. De auto- 
etnograaf is zich constant bewust van de onderhandelingen die gepaard gaan met de constructie van identiteit, omdat zij zelf in constante onderhandeling is over haar identiteiten. Zo handelde ik gedurende mijn onderzoek vanuit ten minste twee expliciete identiteiten: die van de pelgrim en die van de onderzoeker. Dit resulteert in een constante spanning op verschillende fronten - de onderzoeker probeert op de Camino te verantwoorden dat zij nog steeds een pelgrim is, ook al verzamelt zij data onderweg, en de pelgrim legt haar collega's op de universiteit constant uit hoe haar werk als academicus niet wordt ondermijnd door haar deelname aan de pelgrimsgemeenschap. Doordat de auto-etnografische methode een sterke nadruk legt op de positie die een subject inneemt binnen een bepaalde gemeenschap is deze in het bijzonder geschikt als basis voor een onderzoek naar identiteitsconstructie binnen een bepaalde context.

De data die de basis bieden voor het hier gepresenteerde onderzoek zijn verzameld in de periode 2013-2018 (Van der Beek 2018). Deze verzameling is opgebouwd tijdens veldwerk verricht op verschillende pelgrimsroutes naar Santiago de Compostela ${ }^{4}$ in de vorm van participerende observatie en informele interviews. De bevindingen die gedaan zijn aan de hand van deze observaties en gesprekken zijn later getoetst en indien nodig bijgesteld via semigestructureerde interviews met pelgrims die zijn afgenomen in Nederland, online pelgrimsverhalen die gedeeld worden via pelgrimsblogs en Camino-gerelateerde Facebookgroepen, en observaties die zijn verricht tijdens verschillende soorten pelgrims-activiteiten in Nederland, waaronder georganiseerde wandelingen, speciale pelgrimborrels en spirituele bijeenkomsten.

\section{Over gastvrijheid}

De meest gebruikelijke context voor het begrijpen van het concept gastvrijheid is die van ethiek en politiek. De zienswijze werd versterkt door de publicatie van Jacques Derrida's De l'hospitalité (1997) die het concept gastvrijheid benadert vanuit de morele relatie tussen de vreemdeling en de gastvrouw. In deze invloedrijke verhandeling bespreekt Derrida het idee van de onvoorwaardelijke gastvrijheid: een verwelkoming van de vreemdeling zonder oordeel, zonder de conditie van een uitnodiging of zelfs de gebruikelijke papieren ten behoeve van identificatie die grond zou kunnen zijn voor het aanspraak maken op deze gastvrijheid. Deze absolute gastvrijheid vraagt een hoge mate 
van kwetsbaarheid van de gastvrouw en wordt daarom vrijwel nooit gevonden in de echte wereld. In daadwerkelijke manifestaties van gastvrijheid vinden we een dynamische heen-en-weer beweging tussen het verwelkomen van de vreemdeling en het scheppen van afstand tot de vreemdeling.

Veel academische verhandelingen over gastvrijheid zijn gevormd door Derrida's analyse van het concept. Deze analyse blijkt bijvoorbeeld vruchtbaar voor het bespreken van de Europese politiek in de $21^{\mathrm{e}}$ eeuw. ${ }^{5}$ Op de Camino speelt gastvrijheid een andere rol dan in expliciet politieke contexten, maar we herkennen eenzelfde soort afwisseling tussen verwelkomen en afstand scheppen. Deze dynamiek wordt voornamelijk uitgespeeld in de vorm van een uitwisseling tussen de hospitalera en de pelgrim. Wanneer er wordt gesproken over gastvrijheid op de Camino is het gebruikelijk de pelgrim te zien als iemand die gastvrijheid ontvangt. ${ }^{6}$ Echter, de anekdote waarmee dit artikel begon geeft al aan dat op die wijze de situatie te simpel wordt voorgesteld: pelgrims ontvangen gastvrijheid niet simpelweg, pelgrims eisen gastvrijheid. Dit suggereert een transactie in plaats van een gift. Het suggereert dat pelgrims niet alleen iets ontvangen, maar ook iets van waarde terug te bieden hebben aan de gastvrouw. De pelgrimsidentiteit, en de waarde die aan deze identiteit wordt toegekend, is hierin doorslaggevend. Het presenteren, herkennen en bevestigen van identiteit speelt zodanig een belangrijke rol in de dynamiek van gastvrijheid op de Camino.

\section{Gastvrijheid op de moderne Camino de Santiago}

Om te begrijpen waarom de positie van gastvrijheid op de Camino een urgent onderwerp is, introduceer ik eerst een schets van de huidige pelgrimstocht naar Santiago. De 'Camino' is de populaire naam voor de pelgrimstocht die leidt naar de kathedraal van Santiago de Compostela, in het noordwesten van Spanje. In deze kathedraal worden de overblijfselen van de apostel Jakobus de Meerdere vereerd. Deze overblijfselen zouden voor het eerst zijn ontdekt in de negende eeuw op een nabijgelegen locatie. Al snel begonnen pelgrims naar Santiago af te reizen en vorm te geven aan de cultus van Jakobus. Over de eeuwen die volgden, werd deze cultus beïnvloed door religieuze, sociale en politieke ontwikkelingen. Er kan grofweg gesteld worden dat de populariteit van de pelgrimstocht snel op gang kwam, maar aan het einde van de middeleeuwen weer grotendeels was verdwenen. (Melczer 1993; Van Herwaarden 2002; Costen 1993; Andrés-Gallego 2012) Echter, na een lange periode van terugloop beginnen pelgrims sinds de jaren 80 van de vorige eeuw hun weg 
weer te vinden naar Santiago de Compostela. (González 2013; Talbot 2016; Anderson 2016). De drukte op de Camino is tegenwoordig een veelbesproken onderwerp binnen de pelgrimsgemeenschap. In 2018 registreerden maar liefst 327.378 pelgrims zich bij het pelgrimsbureau van de kathedraal van Santiago. Vergelijk dit met de 2.491 pelgrims die zich registreerden in 1986 en de contouren van de transformatie, die zich in de afgelopen decennia op de Camino heeft voltrokken, beginnen zichtbaar te worden.7 Bijna de helft van deze pelgrims komt uit Spanje (44\% in 2018), maar de andere helft vertegenwoordigt bijna 150 verschillende nationaliteiten, pelgrims afkomstig uit heel Europa en ver daarbuiten. Onder deze pelgrims bevinden zich vrome katholieken die afreizen naar Santiago in een ritueel van devotie en gebed. Deze groep is tegenwoordig echter in de minderheid. De meerderheid van de pelgrims heeft geen (expliciet) religieuze motieven voor het deelnemen aan de pelgrimage, maar wijst bijvoorbeeld op de wens om afstand te nemen van het dagelijks leven, om ruimte te geven aan spirituele reflectie, om natuur te ervaren, om een simpel leven te leiden, om nieuwe mensen te ontmoeten, of simpelweg om een bijzondere ervaring te hebben (González 2013; Gardner, Mentley \& Signori 2015; Van der Beek 2018).

Deze twee ontwikkelingen - de toename in het aantal pelgrims en de toename in variatie in de achtergrond en verwachtingen van de pelgrims - heeft geleid tot een fundamentele heroverweging van de Camino als pelgrimstocht: zijn al de participanten aan de Camino eigenlijk wel pelgrims? Kunnen we binnen deze gemeenschap een onderscheid maken tussen pelgrims en niet-pelgrims? Op basis waarvan zou een dergelijk onderscheid kunnen worden gemaakt? En wie heeft de autoriteit om dat onderscheid te bepalen (cf. Cohen 1979; Badone \& Roseman 2004; Margry 2008; Harman 2014; Dunn 2016)? In het verlengde van deze discussie kunnen we ons afvragen: als niet iedereen op de Camino een eigenlijke pelgrim is, moet iedereen op de Camino dan wel behandeld worden als pelgrim? Meer specifiek in de context van dit artikel: kan iedere participant aan de Camino aanspraak maken op de lange traditie van gastvrijheid op de Camino? In de context van recente ontwikkelingen op de Camino kan de verhouding tussen gastvrijheid en de pelgrimsidentiteit een licht werpen op grotere vraagstukken over de Camino als $21^{\mathrm{e}}$ eeuwse pelgrimstocht. 


\section{Gastvrijheid ontvangen}

Het concept van gastvrijheid is nauw verbonden met de traditie van de pelgrimstocht: sinds de eerste golven van pelgrims naar Santiago vertrokken, begon zich een infrastructuur te vormen die voorzag in de vraag naar accommodatie en andere basisbehoeftes van de reizigers. De fundamenten van deze infrastructuur zijn nooit helemaal verdwenen, ondanks de schommelingen in het aantal pelgrims dat er door de eeuwen heen aanspraak op heeft gemaakt. Toen de meest recente herleving van de Camino op gang kwam (zo rond de jaren 80 van de vorige eeuw) nam de Camino opnieuw de taak op om voorzieningen te bieden aan deze nieuwe pelgrims. In de laatste paar decennia zijn er in rap tempo overal nieuwe pelgrimsaccommodaties uit de grond gestampt.

Er bestaat een grote verscheidenheid in het karakter van deze plekken - ze variëren van simpele campings tot luxueuze hotels. Veel pelgrims geven de voorkeur aan accommodaties die speciaal gericht zijn op het onderbrengen van pelgrims. Pelgrims gebruiken voor deze plekken doorgaans het Spaanse woord albergue, of soms het meer archaïsche refugio. Deze albergues zijn specifiek ingericht om te voorzien in de bijzondere behoeftes van de pelgrim: ze bieden een plek om (onwelriekende) wandelschoenen te laten luchten, een plek om de weinige kleren die de pelgrim meedraagt te wassen en te drogen, en een gezamenlijke ruimte waar pelgrims elkaar kunnen ontmoeten. Vaak bieden zij ook een gedeelde keuken waar pelgrims terecht kunnen om de (duurdere) restaurants te omzeilen en een ruimte waar fietspelgrims hun fiets kunnen stallen. Zij zijn bovendien erg goedkoop. Over het algemeen betaalt een pelgrim tussen de 5 en 20 euro per nacht voor een albergue, soms inclusief avondeten en/of ontbijt. Een groot deel van de moderne pelgrims op de Camino heeft toegang tot de welvaart van de westerse wereld, maar toch zijn pelgrims vaak niet bereid veel geld uit te geven zolang zij pelgrim zijn. Deze houding komt deels voort uit de overtuiging dat een pelgrim soberheid zou moeten tonen en dus geen toegang hoort te zoeken tot luxezaken zoals een zacht bed en professioneel bereid eten.

Soberheid is echter geen volledige verklaring, wat opnieuw geillustreerd kan worden door te kijken naar het gedrag van Naomi, die wij ontmoetten in de anekdote waarmee dit artikel begon. Gedurende haar pelgrimstocht weigerde Naomi om fooi te geven. Zij benoemde hiervoor expliciet als reden: "Omdat ik pelgrim ben." Fooi geven zag zij als iets dat een toerist doet. Een toerist heeft immers geen andere manier waarop zij waardering kan uiten. We herkennen hierin delen van de analyse van ethiek in een consumptiemaatschappij van Zygmunt Baumann. Hij beargumenteert dat de postmoderne mens handelt 
als een toerist door gastvrijheid te eisen in ruil voor geld (Baumann 2008, 226-227). Pelgrims, vond Naomi, nemen geen deel aan deze gecommodificeerde relatie tot hun gastvrouwen. Dit sentiment is ook te herkennen in een idee waar veel pelgrims op de Camino bekend mee zijn: dat Spaanse inwoners langs de Camino denken dat het geluk brengt om een pelgrim te helpen. Deze houding suggereert dat de pelgrims iets teruggeven bij de gratie van hun identiteit, bij de gratie van hun 'pelgrimheid'. De pelgrim betaalt de gastvrouw terug door haar de mogelijkheid aan te reiken om gastvrijheid te bieden aan een pelgrim.

Dit is de eerste uitwisseling die plaatsvindt tussen de hospitalera en de pelgrim: de hospitalera biedt specifieke diensten aan de pelgrim en de pelgrim maakt op vanzelfsprekende manier aanspraak op een verlaagde prijs voor deze diensten op basis van haar identiteit als pelgrim.

Tegelijkertijd staan albergues erop dat de gasten die zij ontvangen inderdaad pelgrims zijn. Er wordt van gasten gevraagd dat zij bewijzen dat zij pelgrims zijn door middel van officiële documentatie en het observeren van bijzonder gedrag.

Ten eerste vragen albergues dat iedere gast in het bezit is van zowel een regulier paspoort als van een specifiek pelgrimspaspoort dat gereguleerd wordt door de katholieke kerk in Spanje (een credential genaamd). Beide documenten worden door de hospitalera geïnspecteerd en verwerkt bij de registratiebalie van de albergue. De vraag naar het reguliere paspoort is redelijk recent en is geïnitieerd uit veiligheidsoverwegingen door de Spaanse politie. Het enige doel van de credential is het bevestigen van de pelgrimsidentiteit. Het is overigens niet moeilijk om een credential te bemachtigen - ze zijn voor een paar euro te koop bij verschillende religieuze instituten in Spanje en bij pelgrimsverenigingen over de hele wereld. Maar dit document is het administratieve bewijs van de pelgrimsidentiteit en wanneer een gast dit document niet kan produceren zal haar de toegang tot de albergues geweigerd worden.

In zijn boek over modern toerisme beargumenteert Ruud Welten, in de lijn van Derrida, dat er alleen sprake kan zijn van gastvrijheid wanneer vreemdelingen elkaar ontmoeten. Het ligt besloten in het hart van gastvrijheid, stelt hij, dat wij onze gast niet kennen, haar taal niet begrijpen, maar haar toch erkennen als een volledig mens die aanspraak mag maken op onze aandacht en verzorging (Welten 2013, 156-159). Op de Camino wordt gastvrijheid in albergues juist enkel verstrekt aan gasten die herkenbaar zijn. Niet herkenbaar in de zin van persoonlijk kennen, maar als vertegenwoordiger van een herkenbaar type, dat is: een pelgrim. Door middel van de juiste documentatie presenteren 
pelgrims op de Camino zich als een herkenbaar type aan wie onderdak kan worden geboden in een albergue. Derrida legt uit dat dit proces van herkenbaar maken een perversie is van absolute gastvrijheid, omdat het vraagtekens zet bij de aanwezigheid van de gast en restricties oplegt aan de condities van haar status als gast (Derrida 2000, 135). Het is uiteindelijk een gewelddadig proces, stelt Derrida, dat documentatie inzet om de gast te dwingen tot het aannemen van een specifieke, voorgeschreven en herkenbare positie.

Terugkijkend op mijn eigen ervaringen met het administratieve systeem van de Camino valt mij op hoe weinig weerstand ik ertegen heb ervaren. Het is inderdaad zo dat het strikte hanteren van credentials bij albergues de befaamde gastvrijheid van de Camino ondermijnt. Het vraagt bovendien pelgrims om een pelgrimsidentiteit te vormen rond de structuren van een religieus instituut waar veel pelgrims geen deel van uitmaken. Maar ik heb zelf alleen maar positieve herinneringen aan de keren dat een hospitalera een stempel in mijn credential zette. Eenzelfde gevoel als wanneer een docent vroeger een sticker achter je naam plakte: een teken van goedkeuring, van erkenning. De credential is voor veel pelgrims dan ook een bijzonder document, dat meer vertegenwoordigt dan administratieve erkenning door een anoniem instituut. Het verkrijgen van een credential, meestal voordat de pelgrim op pad gaat, is een van de eerste stappen in de constructie van een pelgrimsidentiteit. En doordat het document op de Camino minstens een keer per dag ter hand wordt genomen, krijgt het gaandeweg een steeds sterkere persoonlijke lading. Het verbaast me dan ook niet dat ik nooit een pelgrim heb gesproken die haar ongenoegen uitte over de verplichte administratie bij albergues. Als ik ernaar vraag halen pelgrims doorgaans hun schouders op, of ze merken op: "Ach, hoe zorg je er anders voor dat de boel netjes verloopt?" Pelgrims hebben weinig tot geen problemen met dit systeem dat uitsluitend gastvrijheid biedt aan diegenen die kunnen aantonen pelgrim te zijn. Er is geen verwachting dat deze gastvrijheid onvoorwaardelijk is. Het tegendeel lijkt het geval: pelgrims zijn tevreden met het feit dat er een voorwaarde wordt gesteld aan de gastvrijheid, omdat het een voorwaarde is die zij, als pelgrims, kunnen en willen vervullen.

Een tweede voorwaarde die albergues stellen aan gasten, is dat zij zich gedragen als pelgrims. Zij staan bijvoorbeeld op bescheidenheid, door het aanbieden van simpele stapelbedden met papieren wegwerp beddengoed in uniseks slaapzalen waar meestal weinig tot geen temperatuurregulering is. Er wordt ook van pelgrims verwacht dat zij genoegen nemen met het delen van de simpele faciliteiten, waaronder de badkamer, de wasruimte en de keu- 
ken. Daarnaast gelden er vaak gedragsregels in albergues. Deze worden soms gecommuniceerd door de hospitalera zelf en soms door middel van briefjes op de muren van de albergue. Voorbeelden van deze instructies zijn "Geen wandelschoenen in de slaapzaal", "Alcohol is niet toegestaan in deze herberg", of "Het is niet toegestaan om blaren te behandelen op de bedden". Pelgrims dienen zich ook te confirmeren aan het dagrooster van de albergue. Dat houdt doorgaans in dat de deuren van de albergue sluiten om tien uur's avonds, de lichten in de albergue uit gaan om elf uur's avonds en dat iedereen het gebouw moet hebben verlaten vóór acht uur 's ochtends. Het is pelgrims gewoonlijk niet toegestaan om langer dan één nacht in een albergue te verblijven - een pelgrim zou immers door moeten lopen, gretig om het uiteindelijke doel van de tocht te bereiken.

Derrida benadrukt dat dergelijke gedragsregels noodzakelijk zijn in de relatie tussen gastvrouw en gast, zodat de gastvrouw de controle over haar huis niet verliest. Immers, wanneer de gastvrouw niet meer de baas is in het huis, kan zij ook geen gastvrijheid meer aanbieden. Het is dus onvermijdelijk dat de gastvrouw een bepaalde mate van macht uitoefent over de gast (Derrida 2000, 151-155). Ook in dit geval tonen pelgrims geen weerstand tegen de regulering van de gastvrijheid die hun wordt geboden, maar zien zij in de regel juist de voordelen van de gedragsregels die hun worden opgelegd. Deze gedragsregels zijn niet hetzelfde in elke albergue, maar het gedrag dat zij beogen is dat grotendeels wel. De regels draaien altijd rond noties van bescheidenheid, soberheid, respect en gemeenschap. Ze garanderen dat iedere gast zich gedraagt als een pelgrim. Het is niet mogelijk om 's nachts te gaan feesten, omdat de deuren van de albergue dicht zullen zijn als je in het holst van de nacht terugkomt. Het is niet mogelijk om lekker lang uit te slapen, omdat de hospitalera je op een bepaald moment buiten de deur zal zetten. De hospitalera maakt het de gasten gemakkelijk om de pelgrimsidentiteit uit te dragen. Zij dwingt de gasten om zich te gedragen als pelgrim door middel van administratieve eisen, de selectie in aangeboden faciliteiten en de geformuleerde gedragsregels.

Dit is een tweede uitwisseling die plaatsvindt tussen de hospitalera en de pelgrim: de pelgrim conformeert zich aan de administratieve regels en de gedragsregels die zij opstelt. Tegelijkertijd helpen deze regels van de hospitalera bij de constructie van de pelgrimsidentiteit van de gasten. 


\section{Gastvrijheid aanbieden}

Nadat ik meerdere malen getuige was geweest van deze dynamiek als pelgrim, besloot ik dat ik wilde ervaren hoe het was om aan de andere kant van de registratiebalie te staan. Het geluk wilde dat Vivian, een vriend van mij, als hospitalero werkte in een albergue op de Camino. In juni 2015 reisde ik af naar zijn albergue om een aantal weken werkzaam te zijn als zijn assistent. Vivian werkte in een particuliere albergue, die, in tegenstelling tot een gemeentelijke albergue, niet door de gemeente wordt gecoördineerd, gereguleerd en gefinancierd. De hospitalera van een gemeentelijke albergue is doorgaans niet betrokken bij de pelgrims die er verblijven nadat de registratie is voltooid. Zij zal de pelgrims misschien helpen om hun plekje te vinden in de albergue of hen juist toespreken wanneer zij de gedragsregels overtreden, maar over het algemeen vertrekt deze hospitalera weer wanneer de bedden van de albergue zijn gevuld. De autoriteit van de hospitalera is daarom vergelijkbaar met de autoriteit die een klerk heeft over haar documenten.

In particuliere albergues gaat het anders. Deze albergues hebben doorgaans een meer idealistisch karakter en worden vaak gerund door vrijwilligers - soms door Spanjaarden, maar vaak ook door buitenlanders, vrijwel altijd door voormalige pelgrims. Deze hospitalera's zijn vaak gemotiveerd om 'iets terug te geven' aan de Camino, waar zijzelf als pelgrims bijzondere ervaringen hebben gehad. Het is bovendien een mogelijkheid om de relatie met de Camino te verlengen nadat de eigenlijke pelgrimstocht is afgerond. Vivian past goed in dit plaatje. In 2014 was hij van het zuiden van Nederland naar Santiago gelopen. Daar was hij omgekeerd om weer terug naar huis te lopen. Op de terugweg stopte hij in een albergue voor een kopje koffie. Daar hoorde hij dat de hospitalera was vertrokken en dat er niemand was die de zaak wilde beheren. Hij bood aan om een dag te komen helpen en bleef er uiteindelijk drie jaar werken.

Het is niet moeilijk om te zien wat het 'teruggeven' van de hospitalero in dit geval behelst. Het duurde slechts een paar uur voor ik me realiseerde hoe hard Vivian voor zijn gasten werkt. Iedere dag is hij de eerste die opstaat - ergens tussen zes en zeven uur 's ochtends - zodat hij iedere pelgrim een ontbijt aan kan bieden en hen uit kan zwaaien wanneer zij hun tocht voortzetten. Nadat de gasten zijn vertrokken trekt hij een paar uur uit om de vloeren, de badkamers en de keuken grondig schoon te maken. Vervolgens wast hij alle lakens (een zeldzaamheid in albergues op de Camino) en is de rest van de dag druk in de weer om ervoor te zorgen dat ze weer droog zijn voor het einde van de dag. Hij legt me uit dat dit schoonmaken voor hem een spirituele 
dimensie heeft: het is zijn manier om zijn gasten te verzorgen en zich met hen te verbinden. De rest van de dag wordt gevuld met het verwelkomen van nieuwe pelgrims en ervoor te zorgen dat zij zich gezien en verzorgd voelen. Iedere avond helpt hij de kok bij het bereiden van het avondeten en dient de maaltijd op aan de gasten. Hierna maakt hij de keuken schoon en voegt zich bij de pelgrims om een drankje met hen te drinken. Hij zorgt ervoor dat hij altijd de laatste is die naar bed gaat, maar dringt er bij de gasten niet op aan om op tijd naar bed te gaan omdat hij hen die vrijheid niet wil ontnemen. Als gevolg ligt Vivian regelmatig pas na middernacht in bed, om vervolgens weer als eerste naast zijn bed te staan.

De bijdrage die Vivian levert aan de Camino is omvangrijk en wordt zeker ook door zijn gasten opgemerkt. Zij waarderen zijn harde werk, maar wat zij nog meer waarderen is zijn kalme vriendelijkheid en zijn woorden van wijsheid. Vivian is een man die tevreden is met zijn spiritualiteit en zijn eigen pelgrimsidentiteit - hij liep immers de indrukwekkende afstand van Nederland tot Santiago. Tijdens mijn periode als zijn collega was ik evenzo onder de indruk van hem en worstelde soms met het claimen van mijn eigen positie als hospitalera naast zijn stralende gastvrijheid. Een incident dat me lang is bijgebleven vond plaats toen ik in het midden van de nacht wakker werd gemaakt omdat een pelgrim een hoge temperatuur had ontwikkeld. Ik ging naar haar toe, gaf haar een kop thee en stelde vast dat er niets ernstigs aan de hand was: het was een ongevaarlijke reactie op het overmatig blootstellen aan de zon tijdens het lopen die dag. De pelgrim had echter geen enkel vertrouwen in mijn oordeel en stond erop dat ik Vivian zou halen. Toen hij wakker was gemaakt, kwam hij naast me op het bed van de pelgrim zitten, keek haar recht in de ogen en zei: "Ik zie wat er hier aan de hand is: je bent overmatig blootgesteld geweest aan de zon tijdens het lopen. Het is niet gevaarlijk. Je kunt gewoon weer gaan slapen.” De volgende morgen bedankte de pelgrim Vivian uitdrukkelijk voor zijn vriendelijke en wijze woorden, terwijl ik achterbleef met het gevoel dat ik volledig was genegeerd en dat mijn gastvrouwschap was ondermijnd. Terugkijkend op dit incident realiseer ik me dat deze pelgrims teruggeven aan Vivian door zijn autoriteit te erkennen als gastheer en verzorger - en derhalve ook hoe het mij stak om te merken dat mijn autoriteit op dat vlak niet op eenzelfde manier werd erkend.

Vaak ontving ik natuurlijk wél waardering voor mijn harde werk en mijn pogingen om de wensen van pelgrims te respecteren. Al snel bereikte ik het punt waarvan Vivian me had verzekerd dat het de indicatie is dat je een echte hospitalera bent geworden: op mijn derde dag vroeg een groep pelgrims me of ze een foto van me mochten maken, zodat ze na thuiskomst herinnerd konden 
worden aan mijn vriendelijkheid. Dat moment, en vele andere momenten met een vergelijkbaar karakter, hebben grote indruk op me gemaakt. Ook Vivian benadrukte meerdere malen dat hij op deze momenten de duidelijkste motivatie vindt om met zijn werk door te gaan. Naast het erkennen van autoriteit, noteerde ik daarom de uiting van dankbaarheid als deel van de uitwisseling tussen de hospitalera en de pelgrim.

Dit is een derde uitwisseling die plaatsvindt tussen de hospitalera en de pelgrim: de hospitalera werkt hard om pelgrims een geschikt onderkomen te bieden en de pelgrim biedt in ruil hiervoor naast dankbaarheid een erkenning van de autoriteit van de hospitalera.

\section{Uitwisselingen tussen de hospitalera en de pelgrim}

Tot zover hebben we drie overeenkomsten benoemd die vormgeven aan de dynamiek tussen de hospitalera en de pelgrim:

1. de hospitalera biedt specifieke diensten aan de pelgrim en de pelgrim maakt op vanzelfsprekende manier aanspraak op een verlaagde prijs voor deze diensten op basis van haar identiteit als pelgrim;

2. de pelgrim conformeert zich aan de administratieve regels en de gedragsregels van de hospitalera. Tegelijkertijd helpen deze regels van de hospitalera bij de constructie van de pelgrimsidentiteit van de gasten;

3. de hospitalera werkt hard om pelgrims een geschikt onderkomen te bieden en de pelgrim biedt in ruil hiervoor naast dankbaarheid een erkenning van de autoriteit van de hospitalera.

Beide partijen lijken op de hoogte van deze dynamiek en houden zich aan de (soms ongeschreven) afspraken. Om te illustreren hoe deze uitwisseling in de praktijk wordt gehanteerd, presenteer ik twee incidenten waarin ik als hospitalera geconfronteerd werd met gasten die niet deel wilden of konden nemen aan deze transacties.

Voorbeeld 1. Tegen het einde van mijn periode als hospitalera was er een Spaans gezin neergestreken op ons terrein. Zij waren niet per se onderweg naar Santiago en dus geen pelgrims, maar wij hadden hun aanwezigheid geaccepteerd omdat zij 'vrienden van de Camino' waren - dat wil zeggen: zij leefden langs de Camino en toonden al de belangrijke kenmerken van een pelgrim (bescheidenheid, soberheid, inclusiviteit etc.). De moeder bracht het 
grootste gedeelte van de dag door met het knutselen van sieraden en de vader van het gezin bood pelgrims reikibehandelingen aan. Zodanig droegen zij ook bij aan de sfeer van de albergue en werden zij door pelgrims gewaardeerd. Na een paar dagen merkten we echter op dat er iets niet helemaal klopte. Eerst kwamen we erachter dat de moeder en vader de pelgrims om geld vroegen voor hun sieraden en reikibehandelingen. Toen begonnen we op te merken dat de familie nooit deelnam aan gezamenlijke activiteiten zoals de avondmaaltijd en de gesprekken bij het kampvuur in de avond. Tot slot had de familie geen enkele interesse in het onderhouden van het contact met Vivian en mij. Na enige tijd vroegen we daarom of het gezin onze albergue wilde verlaten. Deze beslissing was niet gebaseerd op het feit dat zij officieel geen pelgrims waren, maar op ons oordeel dat zij zich niet als pelgrims gedroegen. Dit werd geconstateerd op basis van hun financiële interesse in pelgrims, hun niet-sociale houding, en hun desinteresse in het opbouwen van een band met de gastheer en -vrouw. In dit geval doorbraken de gasten de tweede overeenkomst tussen hospitalera en pelgrim: de gasten conformeerden zich niet aan de gedragsregels die de gastheer en -vrouw hadden voorgeschreven.

Voorbeeld 2. In mijn eerste week als hospitalera arriveerde op een dag, aan het begin van de middag, een bijzondere pelgrim. Hij was een kale, oudere man uit Afrika (een continent dat duidelijk ondervertegenwoordigd is op de Camino) en droeg een feloranje mantel. Hij legde me uit dat hij niet de financiële middelen had om te betalen voor zijn overnachting, maar vroeg me of hij toch aanspraak mocht maken op mijn gastvrijheid. Dat ik hem zonder aarzelen een bed aanbood, was geen blijk van de goedheid van mijn hart. Het was geen onvoorwaardelijke gastvrijheid die ervoor zorgde dat de man die nacht binnen sliep. Het was de onmiskenbare "pelgrimheid" van de man. Waaruit bestond deze? Een grote rol speelde zijn overduidelijk spirituele autoriteit. Deze werd uitgedragen door zijn monnikachtige verschijning, maar ook door zijn vriendelijk glimlachende gezicht, de kalme autoriteit van zijn houding, de manier waarop hij sprak over de fundamentele verbinding die de mensheid samenhoudt. Bovendien beschouwde de man zichzelf als de meest authentieke pelgrim. Als bewijs legde hij ons zijn acht (!) pelgrimspaspoorten voor, allemaal gevuld met stempels. Hij was al 23 jaar onderweg en kon niet bijhouden hoeveel pelgrimstochten hij inmiddels had voltooid. Deze man betaalde niet met geld voor de gastvrijheid die hij ontving, maar hij bood mij de mogelijkheid om me te bewijzen als echte hospitalera, dat wil zeggen: als gastvrouw die de status van de pelgrimsidentiteit waardeert boven geld, als gastvrouw die de traditie van gastvrijheid op de Camino respecteert en 
daarmee laat zien dat zij de commodificatie van de relatie tussen hospitalera en pelgrim afwijst. Dit is een voorbeeld van de eerste overeenkomst tussen de hospitalera en de pelgrim: de pelgrim vergoedt de ontvangen gastvrijheid op basis van zijn status als pelgrim.

\section{Conclusie}

In dit artikel worden de transacties die plaatsvinden rond het verstrekken en het ontvangen van gastvrijheid tussen de hospitalera en de pelgrim op de Camino de Santiago verkend. Het presenteren, herkennen en bevestigen van identiteit spelen een beslissende rol in deze dynamiek. De pelgrim verwacht een zekere mate van gastvrijheid van de Camino, deze verwachting behoort tot het identiteitspakket van de pelgrim. De hospitalera claimt de autoriteit om te beslissen welke gasten de pelgrimsidentiteit bezitten en dus recht hebben op deze gastvrijheid. Deze beslissing wordt gemaakt op basis van het bezit van de juiste papieren en het vertonen van het juiste gedrag. In de interactie tussen de beide figuren, ontvangt de pelgrim naast onderdak een bevestiging van het feit dat zij, inderdaad, een pelgrim is. Zij moet echter in staat zijn om te bewijzen dat ze behandeld dient te worden als pelgrim door middel van documentatie en gedrag. Aan de andere kant van de interactie verstrekt de hospitalera gespecialiseerde gastvrijheid aan de pelgrim en ontvangt in ruil daarvoor een erkenning van haar autoriteit om te beslissen wie wel en niet in het bezit is van de pelgrimsidentiteit.

Derrida's invloedrijke reflecties op de onmogelijkheid van onvoorwaardelijke gastvrijheid worden vaak begrepen in de context van de dynamiek van geweld en controle die een beslissende rol spelen in de manieren waarop gastvrijheid zich daadwerkelijk manifesteert in politiek-ethische conflicten. Dit artikel presenteert een bespreking van de voorwaardelijke gastvrijheid in een andere context, waarin deze dynamiek voornamelijk als positief wordt ervaren door zowel gastvrouwen als gasten. Op de Camino de Santiago wordt de voorwaardelijkheid die verbonden is aan gastvrijheid niet ervaren als gewelddadig, maar juist als een mogelijkheid voor twee specifieke identiteiten om elkaar te herkennen en te bevestigen. De voorwaardelijke gastvrijheid, in de context van de moderne pelgrimstocht naar Santiago de Compostela, biedt een mogelijkheid voor zowel hospitalera als pelgrim om een gewenste identiteit in zichzelf en de ander te bevestigen en versterken. 


\section{Noten}

1 Een noot over taalgebruik in dit artikel. Wanneer het artikel spreekt van 'zij', 'haar' of 'gastvrouw' en er geen directe verwijzing is naar een persoon, kan altijd 'zij/hij', 'haar/hem' of 'gastvrouw/-heer' worden gelezen. Deze keuze is gemaakt om de leesvaardigheid te behouden zonder de normativiteit van de mannelijke persoonsvorm te bevestigen.

2 Alle namen van pelgrims in dit artikel zijn pseudoniemen.

3 Het onderzoek achter dit artikel is uitgevoerd in de context van mijn dissertatieproject. Delen van deze tekst zijn, in bewerkte vorm, opgenomen in dat manuscript. Zie: Van der Beek 2018.

4 De pelgrimsroutes waar veldwerk is verricht zijn de volgende: Camino Francés vanaf Satin-Jean-Pied-de-Port, Camino Portogues vanaf Porto, Camino Sanabres vanaf A Gudiña, Camino Primitivo vanaf Oviedo, Camino del Norte vanaf Ribadesella, en de Camino Finisterra.

5 Zie, bijvoorbeeld: Mireille Rosello's werk over gastvrijheid in een postkoloniale context (2001); Sarah Gibsons werk over asielzoekers (2003); of het werk van Nina HøyPetersen, Ian Woodward en Zlatko Skrbis over gender en kosmopolitisme (2016).

6 Zie bijvoorbeeld de verhandeling van albergues in het nog steeds invloedrijke werk van etnograaf Nancy Frey (1998, 67, 94-100).

7 Bij aankomst in Santiago de Compostela kunnen pelgrims zich laten registreren bij het officiële pelgrimsbureau van de kathedraal. Ieder jaar publiceert het bureau de statistieken van deze registraties op haar website: oficinadelperegrino.com.

\section{Literatuur}

Anderson, Leon (2006),

Analytic Autoetnography, in: Journal of Contemporary Ethnography, 35 (4), 373-395.

Anderson, Linda Kay (2014),

Reformulations of the Pilgrimage to Santiago de Compostela, in: Pazos, Antón M. (ed.), Redefining Pilgrimage. New Perspectives on Historical and Contemporary Pilgrimages, Farnham: Ashgate, 159-181.

Andrés-Gallego, José (2012),

The Politics of Pilgrim Care. A Study in Roncesvalles, in: Pazos Antón, M. (ed.), Pilgrims and Politics: Rediscovering the Power of the Pilgrimage, Farnham: Ashgate, 119150.

Badone, Ellen \& Sharon Roseman (2004),

Intersecting Journeys. The Anthropology of Pilgrimage and Tourism, Urbana and Chicago: University of Illinois Press.

Beek, Suzanne van der (2015).

Als pelgrims online gaan: De invloed van nieuwe media op de Camino, in: Yearbook for Liturgical and Ritual Studies, 31, 77-91. 
Beek, Suzanne van der (2015),

Ritual Authenticity as Social Criticism, in: Post, Paul \& Logan Sparks (eds), The Study of Culture through the Lens of Ritual, Amsterdam: Instituut voor Christelijk Erfgoed/ Institute for Ritual and Liturgical Studies, Netherlands Studies in Ritual and Liturgy, $15,273-285$.

Beek, Suzanne van der (2018),

Pilgrim Writers in Dialogue, in: McIntosh, Ian S., Eileen M. Quinn \& Vivienne Keely (eds), Pilgrimage in Practice. Narration, Reclamation and Healing, Oxford: CABI, 46-59.

Beek, Suzanne van der (2018),

New Pilgrim Stories. Narratives, Identities, Authenticity, Tilburg University, (PhD dissertation).

Bauman, Zygmunt, (2008),

Does Ethics have a Chance in a World of Consumers?, Cambridge (Mass): Harvard University Press.

Cohen, Erik (1979),

A Phenomenology of Tourist Experiences, in: Sociology, 13 (2), 179-201.

Costen, Michael (1993),

The Pilgrimage to Santiago de Compostela in Medieval Europe, in: Reader, Ian \& Tony Walter (eds), Pilgrimage in Popular Culture, London etc: Macmillan Press Ltd, 137-154.

Derrida, Jacques, (2000)

Ofhospitality. (Translated by Rachel Bowlby), Redwood City: Stanford University Press. Dunn, Maryjane (2016),

Historical and Modern Signs of "Real" Pilgrims on the Road to Santiago de Compostela, in: Sánchez y Sánchez, Samuel \& Annie Hesp (eds), Camino de Santiago in the 21st Century, Oxfordshire: Routledge, 13-35.

Frey, Nancy, L. (1998),

Pilgrim Stories, Berkeley: University Press of California,

Gibson, Sarah (2003),

Accommodating Strangers: British Hospitality and the Asylum Hotel Debate, in: Journal for Cultural Research, 7 (4), 367-386.

Gardner, Steven, Carlos Mentley \& Lisa Signori (2015),

Whose Camino Is It? (Re)defining Europe on the Camino de Santiago, in: Sánchez y Sánchez, Samuel \& Annie Hesp (eds), Camino de Santiago in the 21st Century, Oxfordshire: Routledge, 57-77.

González, Rube'n C. Lois (2013),

The Camino de Santiago and its contemporary renewal: Pilgrims, tourists and territorial identities, in: Culture and Religion, 14 (1), 8-22. 
Harman, Lesley D. (2014),

A Sociology of Pilgrimage: Embodiment, Identity, Transformation, Ontario: Ursus Press. Herwaarden, Jan van (2002),

Between Saint James and Erasmus: Studies in Late-Medieval Religious Life-Devotion and Pilgrimage in the Netherlands, Leiden: Brill.

Høy-Petersen, Nina, Ian Woodward \& Zlatko Skrbis (2016),

Gender Performance and Cosmopolitan Practice: Exploring Gendered Frames of Openness and Hospitality, in: The Sociological Review, 64 (4), 970-986.

Margry, Peter Jan (2008),

Shrines and Pilgrimage in the Modern World, Amsterdam: Amsterdam University Press, Melczer, William (1993),

The Pilgrim's Guide to Santiago de Compostela. First English Translation with Introduction Commentaries, and Notes, New York: Italiac Press.

Rosello, Mireille (2001),

Postcolonial Hospitality, Redwood City: Stanford University Press.

Talbot, Lynn (2001),

Revival of the Medieval Past. Francisco Franco and the Camino de Santiago, in: Sánchez y Sánchez, Samuel \& Annie Hesp (eds), The Camino de Santiago in the 21st Century. Interdisciplinary Perspectives and Global Views, London etc: Routledge, 36- 56 .

Welten, Ruud (2013),

Het ware leven is elders, Utrecht: Klement Uitgeverij,

\section{Geraadpleegde websites}

"Statistics" gepubliceerd op de website van het pelgrimsbureau van Santiago de Compostela:oficinadelperegrino.com Geraadpleegd op 4 oktober 2019, via:oficinadel peregrino.com/en/satistics. 